TITLE:

\title{
Hybridizations and genetic relationships among Lindernia species (Scrophulariaceae): L. procumbens and two subspecies of L. dubia
}

\section{$\operatorname{AUTHOR}(\mathrm{S})$ :}

Yoshino, Namiko; Wang, Guang-Xi; Uchino, Akira; Tominaga, Tohru

\section{CITATION:}

Yoshino, Namiko ...[et al]. Hybridizations and genetic relationships among Lindernia species (Scrophulariaceae): L. procumbens and two subspecies of L. dubia. Aquatic Botany 2011, 94(4): 165-171

\section{ISSUE DATE:}

2011-05

URL:

http://hdl.handle.net/2433/139590

\section{RIGHT:}

(c) 2011 Elsevier B.V.; この論文は出版社版でありません。引用の際には 出版社版をご確認ご利用ください。; This is not the published version. Please cite only the published version. 
Hybridizations and genetic relationships among Lindernia species (Scrophulariaceae): L. procumbens and two subspecies of L. dubia

Namiko Yoshino ${ }^{\mathrm{a}, 1}$, Guang-Xi Wang ${ }^{\mathrm{a},{ }^{*}}$, Akira Uchino $^{\mathrm{b}}$, Tohru Tominaga ${ }^{\mathrm{a}}$

${ }^{\mathrm{a}}$ Graduate School of Agriculture, Kyoto University, Kyoto 606-8502, Japan

${ }^{b}$ National Agriculture and Food Research Organization, Ibaraki 305-8666, Japan

${ }^{1}$ Present address: National Agricultural Research Center for Tohoku Region, Fukushima 960-2156, Japan.

*Corresponding author. Tel.: +81 75753 6066; fax: +81 757536062 .

E-mail address: WANG@ weed.mbox.media.kyoto-u.ac.jp (G.-X. Wang). 


\begin{abstract}
Lindernia procumbens and L. dubia are common annual weeds in flooded rice fields of Japan. Two subspecies of L. dubia, subsp. major and subsp. dubia, are usually recognized in Japan but they are both regarded as synonyms of L. dubia elsewhere. In a cluster analysis based on AFLP, most L. dubia subsp. major formed a separate cluster from L. dubia subsp. dubia although $11 \%$ of haplotypes classified using AFLP were not coincident with classification using the shape of leaf bases, which is the commonly used identification trait. Artificial $\mathrm{F}_{1}$ plants between L. procumbens and L. dubia subsp. major, and between L. procumbens and L. dubia subsp. dubia did not produce seed. Forty percent of capsules produced by $\mathrm{F}_{1}$ plants from these two subspecies were slimmer and $80 \%$ pollen were sterile in slimmer capsules. However, seed number of most $F_{1}$ capsules was not different from that of self-fertilized plants, suggesting that there was no complete reproductive isolation between the subspecies. Natural hybridization of these subspecies may have occurred but we are not aware of it because $F_{1}$ plants are rare and $F_{2}$ plants are indistinguishable from these subspecies.
\end{abstract}

Keywords: Lindernia dubia ssp. major, Lindernia dubia ssp. dubia, naturalized species, paddy weed, genetic diversity, Lindernia procumbens, hybridization, AFLP 


\section{Introduction}

Lindernia procumbens (Krock.) Borbas and L. dubia Pennell are very common annual weeds in flooded rice fields in Japan. Genus Lindernia all. is a member of the family Linderniaceae (Rchb.) Borsch, K. Müller, and Eb. Fisch., as distinct from the family Schophulariaceae Juss in APG III (Rahmanzadeh et al., 2005; the angiosperm phylogeny group, 2009). Lindernia procumbens is an archaeophyte species in Japan (Yamazaki, 1993), whereas L. dubia, native to North America, was listed as a naturalized plant in 1954 (Yamazaki, 1954). L. dubia has recently increased rapidly (Yoshino et al., 2006a) and is now more common than the native species. In the last fifteen years, biotypes of these weeds, resistant to sulfonylurea herbicides, have been frequently found and their distribution in Japan has increased (Uchino and Watanabe, 2002; Uchino, 2003).

Two distinct subspecies of L. dubia were described by Pennell (1935), L. dubia subsp. major and L. dubia subsp. dubia. This classification of subspecies is now commonly applied in Japan. These subspecies are distinguished typically by the shape of the base of their leaves; subsp. major has a cuneate leaf base while subsp. dubia has a round leaf base Morita (1994). This classification of subspecies, however, is apparently not used outside of Japan and the names of subspecies are regarded as synonyms of $L$. dubia (Copperrider and McCready, 1975; Delipavlov \& Cheshmejiev, 1984; Carretero, 1985; Chaw \& Kao, 1989; Conesa \& Recasens, 1989; Kallen, 1994; Seliskar et al., 1995; López, 1997; Lewis, 2000). Nonetheless, the two subspecies seem to be distinct from each other in Japan because very few intermediate or mixed types are found, although they have been distributed sympatrically in rice fields in Japan since the 1960s (Yoshino et al., 2006a). 
In this study, we verified the possibility of hybridization among the Lindernia weeds including a native species, $L$. procumbens, by artificial hybridizations, and surveyed the genetic relationships among them by Amplified Fragment Length Polymorphism (AFLP) analysis to assess the validity of the classification of Lindernia weeds in Japan. In addition, the genetic distance based on AFLP analysis was analyzed in relation to geographical distance, and we discussed the differentiations of Lindernia weeds from the point of view of naturalization.

\section{Materials and methods}

\subsection{Sample collection for AFLP}

Lindernia procumbens, L. dubia subsp. major and L. dubia subsp. dubia were sampled across Japan from 9, 10 and 10 populations, respectively. Each population consisted of 2 or 3 individuals. Lindernia procumbens plants were sampled at Sobetsu $\left(42^{\circ} 33 \mathrm{~N}, 140^{\circ} 46 \mathrm{E}\right)$, Nagai $\left(38^{\circ} 6 \mathrm{~N}, 140^{\circ} 2 \mathrm{E}\right)$, Tsukuba $\left(36^{\circ} 5 \mathrm{~N}, 140^{\circ} 6 \mathrm{E}\right)$, Kyoto $\left(35^{\circ} 5 \mathrm{~N}\right.$, $\left.135^{\circ} 47 \mathrm{E}\right)$, Uji $\left(34^{\circ} 54 \mathrm{~N}, 135^{\circ} 46 \mathrm{E}\right)$, Bizen $\left(34^{\circ} 45 \mathrm{~N}, 134^{\circ} 13 \mathrm{E}\right)$, Hongo $\left(34^{\circ} 25 \mathrm{~N}\right.$, $\left.132^{\circ} 59 \mathrm{E}\right)$, Katsuyama $\left(33^{\circ} 36 \mathrm{~N}, 130^{\circ} 35 \mathrm{E}\right)$ and Hiyoshi $\left(31^{\circ} 15 \mathrm{~N}, 130^{\circ} 28 \mathrm{E}\right)$. Lindernia dubia subsp. major plants were sampled in Taiwa $\left(38^{\circ} 15 \mathrm{~N}, 140^{\circ} 55 \mathrm{E}\right)$, Asahi $\left(38^{\circ} 19 \mathrm{~N}\right.$, $\left.140^{\circ} 9 \mathrm{E}\right)$, Kawanishi $\left(38^{\circ} 0 \mathrm{~N}, 140^{\circ} 3 \mathrm{E}\right)$, Yabuki $\left(37^{\circ} 12 \mathrm{~N}, 140^{\circ} 20 \mathrm{E}\right)$, Tsukuba, Otsu $\left(35^{\circ} 4 \mathrm{~N}, 135^{\circ} 52 \mathrm{E}\right)$, Kyoto, Uji, Yamaga $\left(33^{\circ} 26 \mathrm{~N}, 131^{\circ} 31 \mathrm{E}\right)$ and Makurazaki $\left(31^{\circ} 16 \mathrm{~N}\right.$, $130^{\circ} 18 \mathrm{E}$ ). Lindernia dubia subsp. dubia plants were sampled in Yokohama (Aomori, $\left.41^{\circ} 5 \mathrm{~N}, 141^{\circ} 15 \mathrm{E}\right)$, Moriyoshi $\left(39^{\circ} 43 \mathrm{~N}, 140^{\circ} 16 \mathrm{E}\right)$, Yabuki, Tsukuba, Yatomi $\left(35^{\circ} 6 \mathrm{~N}\right.$, $\left.136^{\circ} 44 \mathrm{E}\right)$, Kyoto, Uji, Hongo, Katsuyama and Makurazaki. The collection was obtained in three ways: seeds, seed banks in soil samples and fresh leaves. Seed samples were collected from mature plants at each field site and these seeds were planted and grown 
on the Kyoto University farm; fresh leaves were collected about $60 \mathrm{~d}$ after sowing. Soil samples collected at each paddy field site were irrigated in pots and germinated plants were collected about $60 \mathrm{~d}$ after irrigation commenced. Fresh leaves were collected directly from plants and refrigerated at each sampling site. We identified L. dubia with cuneate leaf bases as L. dubia subsp. major and those with round leaf base as L. dubia subsp. dubia. All leaves were treated with liquid nitrogen and stored at $-80{ }^{\circ} \mathrm{C}$ before DNA extraction.

\subsection{AFLP fingerprinting}

Leaf samples of about $100 \mathrm{mg}$ were crushed using a multi-beads shocker (Yasui Kikai, Osaka, Japan) at 2,000 (smash intensity) for $5 \mathrm{~s}$ after freezing in liquid nitrogen. Genomic DNA was extracted according to a partly modified CTAB method of Doyle and Doyle (1990). AFLP fingerprinting was conducted using a partly modified method of Vos et al. (1995) using a thermal cycler (Sequi-Gen GT, Bio-Rad, California, U.S.). The restriction enzyme digestion and the ligation were conducted using AFLP Core Reagent Kit (Invitrogen, California, U.S.). PCR products were separated by polyacrylamide gel electrophoresis using Sequi-Gen GT Sequencing Cell (Bio-Rad, 165-3863, $38 \times 50 \mathrm{~cm}$, California, U.S.) and Electrophoresis Power Supply EPS 3500 XL (Amersham Bioscience, U.K.), using their partially-modified manuals. After electrophoresis, gels were stained by a silver staining method with Silver SequenceTM DNA Sequencing System (Promega, Wisconsin, US).

The genotypes were visually scored within 100 to $500 \mathrm{bp}$. Genetic distance between each pair of individuals was calculated using the Dice distance coefficient obtained as (1-Dice similarity index) (Dice, 1945). The genetic distances obtained were used for 
cluster analysis using UPGMA with 1000 bootstraps by using the Clustering Calculator Program (Brzustowski, 2002) and TreeView 1.6.6 (Page, 1996). Genetic diversities of total populations $\left(H_{T}\right)$, within each population $\left(H_{S}\right)$ and among populations $\left(G_{S T}\right)$ were calculated using Nei’s (1978) unbiased genetic distance with POPGENE 1.32.

\subsection{Artificial hybridization}

Lindernia procumbens, L. dubia subsp. major and L. dubia subsp. dubia were sampled in the paddy field at the Kyoto University farm and served as parents for artificial hybridization. They were transplanted into $430 \mathrm{~mL}$ plastic cups filled with paddy soil and grown in flooded conditions, then covered with $2 \mathrm{~mm}$ mesh cloth to avoid pollination by insects. Hand pollination was conducted after flowering under an anatomic microscope between 8:00 a.m. and 10:00 a.m. on sunny mornings. After ripening of seeds, we counted the number of seeds in the capsules obtained by hand pollination and these seeds were stored in the refrigerator at $7{ }^{\circ} \mathrm{C}$. Selfing progeny were also made and saved in the same way as hybridized plants.

$F_{1}$ plants were grown from this seed in a greenhouse and in a growth chamber. In the greenhouse on the Kyoto University farm, we planted $F_{1}$ seeds in $430 \mathrm{~mL}$ plastic cups filled with paddy soil and $F_{1}$ plants were grown under natural temperature and light conditions. In the growth chamber NC-220S(C) (Nippon Medical \& Chemical Instruments Co., Ltd., Osaka, Japan), plants were grown in plastic boxes with 24 cells $(3 \mathrm{~cm} \times 3 \mathrm{~cm})$ filled with peat moss (Golden peat ban, Sakata Seed Corporation, FH-180) at $30{ }^{\circ} \mathrm{C}$ under standard fluorescent light condition for 16 hours and $25^{\circ} \mathrm{C}$ dark condition for 8 hours. In both greenhouse and chamber experiments, 30 seeds from one capsule were sown in the same cup or box. Germinated plants were counted on the 30th 
day after sowing. After counting, plants were thinned, allowing the most vigorous plants to remain. The growth of $F_{1}$ plants was evaluated for the following five categories.

The pollen staining was conducted with $10 \mu \mathrm{L}$ fixing solution (ethanol: acetic acid $=$ $3: 1)$ and $10 \mu \mathrm{L}$ of stain solution ( $1 \%(\mathrm{w} / \mathrm{v})$ blue cotton; $50 \%$ glycerin solvent). Pollen morphology was observed under an optical microscope and the number of pollen grains was counted. Based on three morphological traits (Yoshino et al. 2007), $\mathrm{F}_{1}$ plants were divided into three types: those like L. dubia subsp. major, those like L. dubia subsp. dubia and an intermediate type between these subspecies. All $\mathrm{F}_{1}$ plants grown in both greenhouse and growth chamber were used for seed counting, pollen staining and examining potentially diagnostic morphological traits.

\section{Results}

\subsection{Genetic relationships based on AFLP fingerprinting and Relationships between} genetic and geographical distance

Lindernia procumbens populations had more loci than $L$. dubia subsp. major and $L$. dubia subsp. dubia populations (Table 1). Lindernia procumbens formed a single cluster that was completely separated from another cluster consisting of the two subspecies of $L$. dubia in the cluster analysis based on AFLP fingerprinting (Fig. 1).

The L. dubia cluster included two sub-clusters. Group A included most of L. dubia subsp. major and group B included most of L. dubia subsp. dubia. Only two (2031 and 2091) of the 27 L. dubia subsp. major belonged to group B, and four $(3103,3153,3181$ and 3183) of 24 L. dubia were located in group A.

The genetic distance between L. procumbens plants was correlated with the geographical distance of their collection site, although no such correlation was observed 
in L. dubia subsp. major and L. dubia subsp. dubia (Fig. 2). The genetic distance of $L$. dubia subsp. dubia had two peaks regardless of their geographical distance.

\subsection{Artificial hybridization}

The mean seed number was significantly higher in the combinations of L. dubia subsp. major and L. dubia subsp. dubia than the other combinations including $L$. procumbens (Table 2). The combination of L. dubia subsp. dubia $\times$ L. procumbens did not produce any seeds. In $F_{1}$ plants, only the progeny of the combination of the two subspecies formed capsules while any other combinations including L. procumbens did not produce capsules. The rate of $F_{1}$ plants that produce capsules was not significantly different from that of self-fertilized plants by chi-test ( $p>0.05$, data not shown). However, $40 \%$ of the produced capsules were slimmer in the $\mathrm{F}_{1}$ plants while $97 \%$ of capsules of selfing progeny of their parents were normal. The slimmer capsules had fewer seeds, $68 \%$ of slimmer capsules had less than 100 seeds per capsule while $94 \%$ of normal capsules had more than 101 seeds per capsule (data not shown).

\subsection{Pollen fertility and morphology of $F_{1}$ plants between L. dubia subsp. major and $L$.} dubia subsp. dubia

Pollen of $\mathrm{F}_{1}$ offspring of crosses between L. dubia subsp. major and L. dubia subsp. dubia were classified as fertile uniformly stained circular, and sterile unstained and/or non-circular. The anthers of plants which formed narrower capsules contained $20 \%$ fertile pollen, while normal capsules contained $91 \%$, showing a significant difference between narrower and normal capsules ( $\mathrm{p}<0.001$ by t test).

Upon visual inspection, $\mathrm{F}_{1}$ plants were clearly different from either of their parents 
and either of selfing progeny of the parents. Above ground plant length was longer in $F_{1}$ plants than in the selfing progeny of their parents and $\mathrm{F}_{1}$ plants bent at their nodes and crept on the ground (data not shown).

The leaf shape (b in Table 3) and the shape of leaf base (c in Table 3) of $F_{1}$ plants were the same as L. dubia subsp. dubia and the depth of the leaf teeth (d in Table 3 ) and floral arrangement (e in Table 3) of $\mathrm{F}_{1}$ plants were the same as L. dubia subsp. major. Petals of $\mathrm{F}_{1}$ plants had purple spots like L. dubia subsp. dubia but these spots were paler than L. dubia subsp. dubia (a in Table 3).

\section{Discussion}

Lindernia procumbens is a prehistoric-naturalized plant to Japan and hence might have become geographically differentiated in Japan. Despite the earlier naturalization of L. dubia subsp. major than L. dubia subsp. dubia, its genetic diversity was smaller than L. dubia subsp. dubia. The genetic diversity of $L$. dubia subsp. dubia was the same as $L$. procumbens, suggesting the multiple invasion of $L$. dubia subsp. dubia to Japan.

Lindernia procumbens formed an independent cluster by AFLP and $\mathrm{F}_{1}$ between $L$. procumbens and L. dubia did not produce seed. These results were consistent with the notion that L. procumbens and L. dubia are different species.

Most classification decisions based on the shape of the leaf base of $L$. dubia agreed with the results of AFLP analysis. However, the results showed that the classification based on leaf base shape was insufficient to classify L. dubia subsp. major and L. dubia subsp. dubia. The round leaf base of $L$. dubia subsp. dubia appeared to be dominant over the cuneate leaf base of L. dubia subsp. major, and therefore the plants with the round leaf bases seem to include the hybrid plants between these subspecies. Most of 
the plants whose haplotypes did not coincide with classification by leaf bases were expected to have a round leaf base. Therefore, identification not only by leaf base shape, but also by other taxonomic characters, e.g. pedicel length, might be necessary to distinguish them (Yoshino et al. 2006b).

From the results of the artificial hybridization, there was no complete reproductive isolation between L. dubia subsp. major and L. dubia subsp. dubia, while $L$. procumbens is genetically isolated from two subspecies of $L$. dubia. It is possible that hybrids between these subspecies are distributed in Japan.

The morphology of $F_{1}$ Plants was not affected by the reciprocal crosses. Inheritance mode of petal color pattern, paler petal spots, seemed to be codominant in L. dubia. The codominant inheritance mode in flowers color was similar to related species such as Antirrhinum, Mimulus and Torenia (Bradshaw et al., 1995; Aida et al., 2000; Jones et al., 2001). Plant length of $F_{1}$ plants showed heterosis by hybridization but did not show reproductive success because $F_{1}$ plants were creeping, which would not seem to confer a selective advantage in a rice field. Narrow capsules were the result of decreased seed number, due to sterile pollen, and capsule shape itself did not seem to change by genetic factors.

As plants with the same morphological character to artificial $F_{1}$ plants were not found in either fields or herbarium specimens, $F_{1}$ plants were thought to exist rarely under natural conditions because L. dubia is a self-fertilizing species with cleistogamous flowers which normally self-pollinates (Ikeda and Miura, 1994; Morita, 1994). However, hybridization of these subspecies has accidentally occurred, and some $F_{1}$ plants have had fertile seeds because they are distributed sympatrically in many rice fields in Japan (Yoshino et al., 2006a). $\mathrm{F}_{2}$ and later progeny would be expected to have 
the same reproductive ability as their parents.

In most of these subspecies samples, classification based on leaf base shape was consistent with the results of AFLP analysis, and the haplotypes were different between the two subspecies. Therefore, we conclude that it is appropriate to distinguish the two subspecies taxonomically and the infraspecific rank such as subspecies or variety would appear adequate, because of the rare possibility of natural hybridization between them. Distributions of these subspecies overlapped extensively in United Status and Japan (Pennell, 1935; Yoshino et al., 2006a). 'Variety' may be more appropriate than 'subspecies' because naturally occurring plants with overlapping distributions have tended to be classified as varieties (Hamilton and Reichard, 1992).

\section{Acknowledgements}

The authors want to thank Prof. Bruce Auld and Dr. Breen John for correcting the English and providing valuable comments on an earlier draft, and two anonymous reviewers for their improvements to the manuscript.

\section{References}

Aida, R., Kishimoto, S., Tanaka, Y., Shibata, M., 2000. Modification of flower color in torenia (Torenia fournieri Lind.) by genetic transformation. Plant Sci 153, 33-42. The angiosperm phylogeny group, 2009. An update of the Angiosperm Phylogeny Group classification for the orders and families of flowering plants: APG III. Bot. J. Linn. Soc. 161, 105-121.

Bradshaw, H.D., Wilbert, S.M., Otto, K.G., Schemske, D.W., 1995. Genetic-mapping of floral traits associated with reproductive isolation in monkeyflowers (Mimulus). 
Nature 376, 762-765.

Brzustowski, J., 2002. Clustering Calculator Program.

http://www2.biology.ualberta.ca/jbrzusto/cluster.php http, //www2.biology.ualb.

Carretero, J.L., 1985. A contribution to the study of exotic flora in the province of Valencia. Collect. Bot. 16, 133-136 (in Spanish).

Chaw, S.M., Kao, M.T., 1989. Lindernia dubia var. anagallidea (Michaux) Pennell (Scrophulariaceae) -a newly naturalized plant in Taiwan. J. Taiwan Mus. 42, 95-100.

Conesa, J.A., Recasens, J., 1989. Contribution to the knowledge of the western Catalan flora, II. Folia Bot. Misc. 6, 93-102 (in Catalan with English abstract).

Cooperrider, T.S., McCready, G.A., 1975. On separating Ohio specimens of Lindernia dubia and L. anagallidea (Scrophulariaceae). Castanea 40, 191-197.

Delipavlov, D.D., Chechmejiev, I.V., 1984. New data and some critical reviews for Bulgarian flora. Fitologija 26, 60-68 (in Bulgarian with English abstract).

Dice, L.R., 1945. Measures of the amount of ecological association between species. Ecology 26, 297-302.

Doyle, J.J., Doyle, J.L., 1987. A rapid DNA isolation procedure for small quantities of fresh leaf tissue. Phytochem. Bull. 19, 11-15.

Hamilton, C.W., Reichard, S.H., 1992. Current practice in the use of subspecies, variety, and forma in the classification of wild plants. Taxon 41, 485-498.

Ikeda, E., Miura, R., 1994. A note on the proportion of cleistogamous flowers in Lindernia dubia (L.) Pennell (Scrophulariaceae) in a paddy field. J. Weed Sci. Technol. 39, 177-179.

Itoh, K., Wang, G.-X., Ohba, S., 1999. Sulfonylurea resistance in Lindernia micrantha, an annual paddy weed in Japan. Weed Res. 39, 413-423. 
Jones, K.N., Reithel, J.S., 2001. Pollinator-mediated selection on a flower color polymorphism in experimental populations of Antirrhinum (Scrophulariaceae). Am. J. Bot. $88,447-454$.

Kallen, H.W., 1993. Das große Büchsenkraut Lindernia dubia (L.) Pennell im Elbtal zwischen Lauenburg und Wittenberge. Florist. Rundbr. 27, 107-109 (in German with English abstract).

Lewis, D.Q., 2000. A revision of the New World species of Lindernia (Scrophulariaceae). Castanea 65, 93-122.

López, M.L., 1997. Fragmenta chorologica occidentalia, 6275-6280. An. Jard. Bot. Madr. 55, 433-455 (in Spanish).

Morita, A., 1994. Morphological study of paddy Lindernia weeds in Japan. Shokucho 28, 223-228 (in Japanese).

Nei, M., 1978. Estimation of average heterozygosity and genetic distance from a small number of individuals. Genetics 89, 583-590.

Page, R.D.M., 1996. Tree View: An application to display phylogenetic 2 trees on personal computers. Comput. Appl. Biosci. 12, 357-358.

Pennell, W.F., 1935. The Scrophulariaceae of Eastern Temperate North America. Carpenter Fund, Philadelphia.

Rarmanzadeh, R., Müller, K., Fischer, E., Bartels, D., Borsch, T., 2005. The Linderniaceae and Gratiolaceae are further lineages distinct from the Scrophulariaceae (Lamiales). Plant Biol. 7, 67-78.

Seliskar, A., Trpin, D., Vres, B., 1995. Flora and vegetation on wet habitats in Slovenia. -I. Genus Lindernia All. Biol. Vestn. 40, $45-58$ (in Slovenian with English abstract). Shibaike, H., Akiyama, H., Uchiyama, S., Kasai, K., Morita, T., 2002. Hybridization 
between European and Asian dandelions (Taraxacum section Ruderalia and section Mongolica) 2. Natural hybrids in Japan detected by chloroplast DNA marker. J. Plant Res. 115, 321-328.

Uchino, A., 2003. Resistance to ALS-inhibiting herbicides in weeds. J. Pestic. Sci. 28, 479-483.

Uchino, A., Watanabe, H., 2002. Mutations in the acetolactate synthase genes of sulfonylurea-resistant biotypes of Lindernia spp. Weed Biol. Manag. 2, 104-109.

Uchino, A., Watanabe, H., 2007. Effects of pyruvate and sucrose on acetolactate synthase activity in Lindernia species and Schoenoplectus juncoides in an in vivo assay. Weed Biol. Manag. 7, 184-187.

Uchino, A., Watanabe, H., Wang, G.X., Itoh, K., 1999. Light requirement in rapid diagnosis of sulfonylurea-resistant weeds of Lindernia spp. (Scrophulariaceae). Weed Technol. 13, 680-684.

Vos, P., Hogers, R., Bleeker, M., Reijans, M., Vandelee, T., Hornes, M., Frijters, A., Pot, J., Peleman, J., Kuiper, M., Zabeau, M., 1995. AFLP - A new technique for DNA-fingerprinting. Nucleic Acids Res. 23, 4407-4414.

Yamaguchi, H., Mukai, E., Nakayama, Y., 2005. A genetic evaluation on Lindernia species emerged from seed-bank in a wetland restoration in Azamenose site, the Matsuura River, Saga prefecture, Japan. Scientific report of the Graduate School of Agriculture and Biological Sciences, Osaka Prefecture University 57, 25-32 (in Japanese with English abstract).

Yamazaki, T., 1993. Scrophulariaceae. In: Iwatsuki, K., Yamazaki, T., Boufford, D.E. and Ohba H. (Eds.,) Flora of Japan, Volume IIIa, Angiospermae Dicotyledoneae Sympetalae. Kodansha, Tokyo, pp. 336-341. 
Yamazaki, T., 2003. Scrophulariaceae. In: Shimizu, T. (Eds.,) Naturalized plants of Japan. Heibonsha Ltd., Tokyo, pp. 187 (in Japanese).

Yamazaki, T., 1954. Notes on Lindernia, Vandellia, Torenia and their allied genera in Eastern Asia 1. Shokubutsu Kenkyu Zasshi 29, 299-306 (in Japanese).

Yoshino, N., Wang, G.X., Ito, M., Tominaga, T., 2006b. Flower arrangement patterns of three paddy weeds, Lindernia procumbens, L. dubia subsp. dubia and L. dubia subsp. major. J. Weed Sci. Technol. 51, 82-86 (in Japanese).

Yoshino, N., Wang, G.-X., Itoh, M., Auld, B., Kohara, H., Enomoto, T., $2006 a$. Naturalization and dissemination of two subspecies of Lindernia dubia (Scrophulariaceae) in Japan. Weed Biol. Manag. 6, 174-176.

Yoshino, N., Wang, G.-X., Tominaga, T., 2007. Irrigation time affects duration of emergence and flowering of paddy weeds, Lindernia procumbens and L. dubia subsp. dubia, but not L. antipoda. Tohoku Weed J. 7, 21-26 (in Japanese). 


\section{Figure legends}

Fig. 1. UPGMA cluster of L. procumbens (1 ---), L. dubia subsp. major (2 ---) and L. dubia subsp. dubia (3 ---) in Japan. Bar shows the genetic distance. Italic figures show the 1000 times trials of the bootstrap value. Sampling sites were 1011, 1013: Sobetsu; 3021 3023: Yokohama; 2031 2033: Taiwa; 3041 3043: Moriyoshi; 1051 1053: Nagai; 2061 2063: Asahi; 2071 2073: Kawanishi; 2081 2083, 3081 3083: Yabuki; 1091, 2091, 2092, 3091: Tsukuba; 3101 3103: Yatomi; 2111 2113: Otsu; 1121 1123, 2121 2123, 3121 3123: Kyoto; 1131 1133, 2131 2133, 3131 3133: Uji; 1141 1143: Bizen; 1151 1153, 3151 3153: Hongo; 1161, 1163, 3161 3163: Katsuyama; 2171 2173: Yamaga; 2181 2183, 3181 3183: Makurazaki; 1191, 1192: Hiyoshi.

Fig. 2. The relationship between genetic and geographical distance of $L$. procumbens, L. dubia subsp. major and L. dubia subsp. dubia. Regression equation and coefficient of determination for L. procumbens, L.dubia subsp. major and L. dubia subsp. dubia were $\mathrm{y}=11.45 \times 10^{-5} \mathrm{x}+0.11, \mathrm{R}^{2}=0.3618, \mathrm{y}=0.76 \times 10^{-5} \mathrm{x}+0.08, \mathrm{R}^{2}=$ $0.0052, \mathrm{y}=8.66 \times 10^{-5} \mathrm{x}+0.11 \mathrm{R}^{2}=0.1141$, respectively. Lindernia procumbens and $L$. dubia subsp. dubia were significant $(\mathrm{p}=0.001)$, though L.dubia subsp. major was not significant $(\mathrm{p}>0.05)$. 
Fig. 1 -Yoshino et al. - Top $\uparrow$

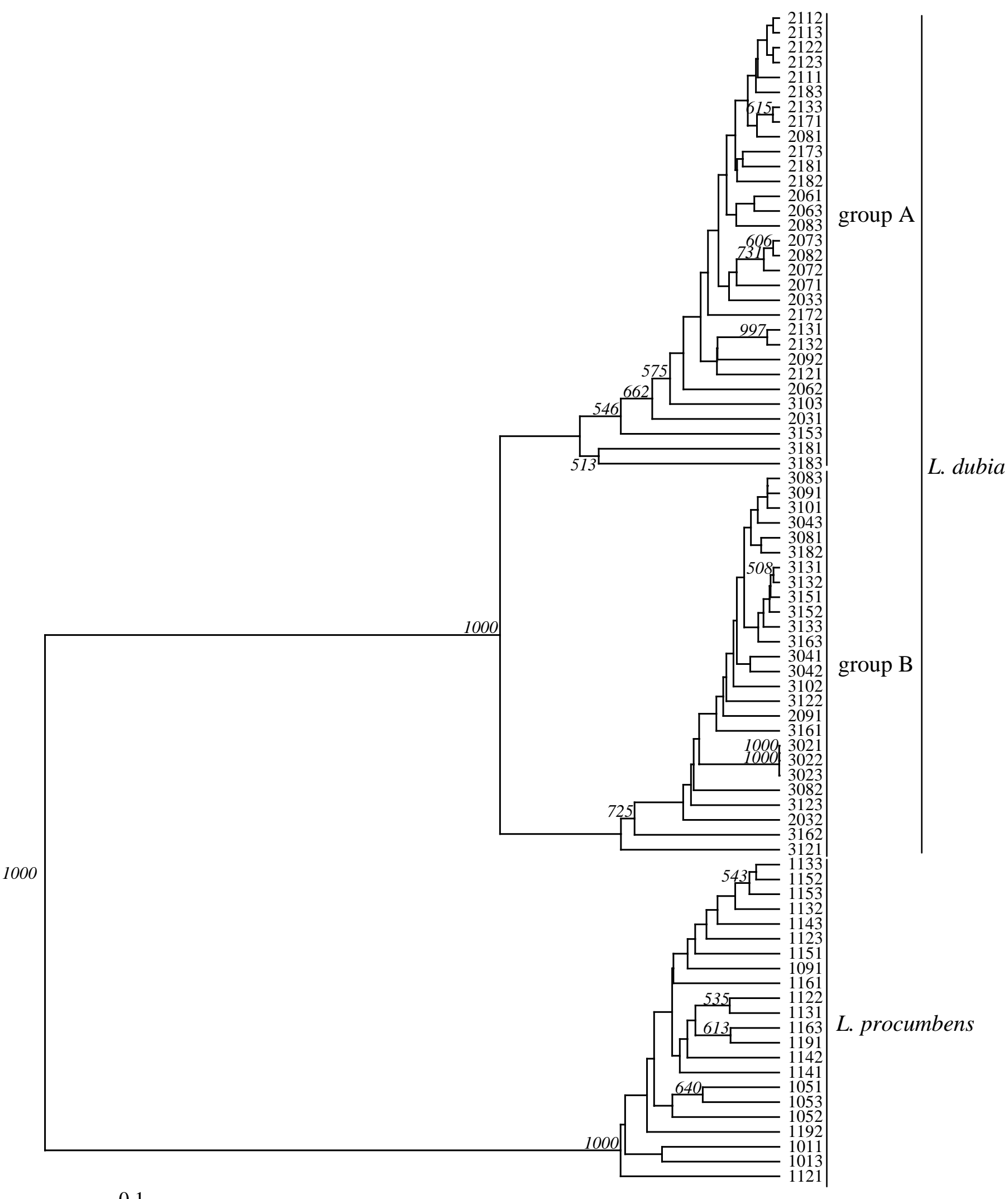


Fig. 2 -Yoshino et al. - Top $\uparrow$

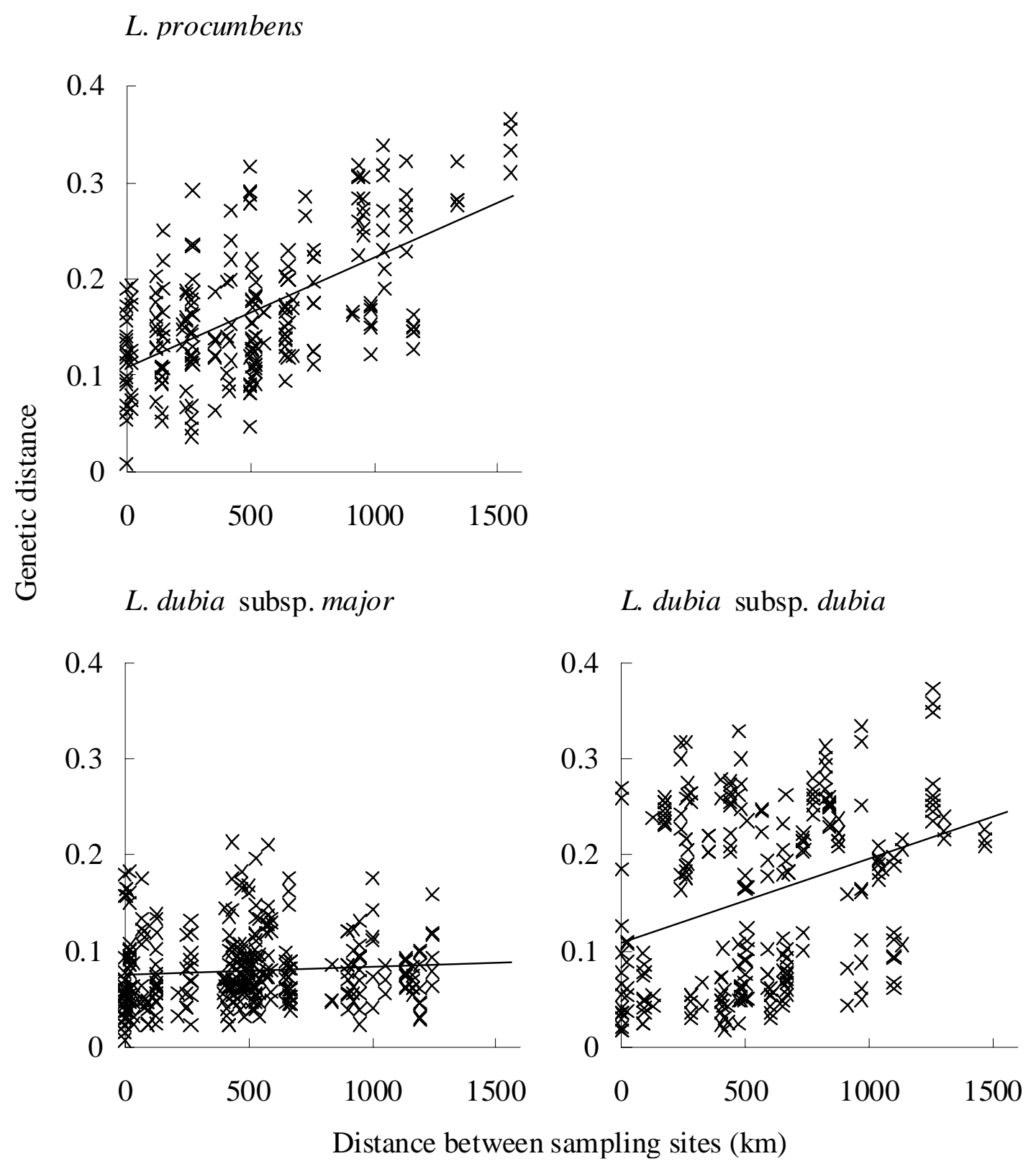


Table 1 Genetic distance and genetic diversity of L. procumbens, L. dubia subsp. major and L. dubia subsp. dubia from AFLP fingerprinting.

\begin{tabular}{|c|c|c|c|c|c|}
\hline & & L. procumbens & $\begin{array}{l}\text { L. dubia } \\
\text { subsp. major }\end{array}$ & $\begin{array}{l}\text { L. dubia } \\
\text { subsp. dubia }\end{array}$ & Total \\
\hline Number of individuals & & 22.0 & 27.0 & 23.0 & 74.0 \\
\hline Number of populations & & 9.0 & 10.0 & 10.0 & 30.0 \\
\hline Number of alleles & & 145.0 & 116.0 & 98.0 & 279.0 \\
\hline Number of unique alleles & & 86.0 & 22.0 & 12.0 & \\
\hline Number of polymorphic alleles & & 55.0 & 36.0 & 25.0 & 167.0 \\
\hline 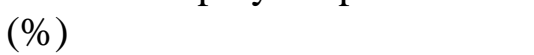 & & 37.9 & 31.0 & 25.5 & 59.9 \\
\hline Average number of bands & & 76.7 & 69.7 & 72.1 & 72.4 \\
\hline \multirow{3}{*}{$\begin{array}{l}\text { Genetic distance (minimum - } \\
\text { maximum) }\end{array}$} & L. procumbens & $0.012-0.133$ & $0.685-1.024$ & $0.664-0.872$ & \\
\hline & L. dubia subsp. major & & $0.003-0.090$ & $0.134-0.253$ & \\
\hline & L. dubia subsp. dubia & & & $0-0.113$ & \\
\hline \multirow[t]{3}{*}{ Genetic diversity } & All populations $\left(H_{T}\right)$ & 0.23 & 0.19 & 0.24 & \\
\hline & Each population $\left(H_{S}\right)$ & 0.20 & 0.15 & 0.21 & \\
\hline & Coefficient of differentiation $\left(G_{S T}\right)$ & 0.13 & 0.21 & 0.13 & \\
\hline
\end{tabular}


Table 2 Growth of $\mathrm{F}_{1}$ and self-fertilization plants of L. procumbens, L. dubia subsp. major and L. dubia subsp. dubia.

\begin{tabular}{|c|c|c|c|c|c|c|c|c|c|c|}
\hline \multirow[b]{2}{*}{ Combination } & & \multicolumn{2}{|c|}{ Number of Seeds } & \multicolumn{5}{|c|}{$\%$ of plants } & \multicolumn{2}{|c|}{$\mathrm{p}$ value of chi test } \\
\hline & & & & $\begin{array}{l}\text { No } \\
\text { germina } \\
\text { tion } \\
(1)^{*}\end{array}$ & $\begin{array}{l}\text { No } \\
\text { flower } \\
\text { (2) }\end{array}$ & $\begin{array}{l}\text { No seeds } \\
\text { (3) }\end{array}$ & $\begin{array}{l}\text { A few } \\
\text { seeds } \\
(4)\end{array}$ & $\begin{array}{l}\text { Normal } \\
\text { (5) }\end{array}$ & $\begin{array}{l}\text { Vs. } \\
\text { reciproc } \\
\text { al } \\
\text { crosses }\end{array}$ & $\begin{array}{l}\text { Vs. self } \\
\text { fertilizat } \\
\text { ion }\end{array}$ \\
\hline $\mathrm{F}_{1}$ & $\begin{array}{l}\text { L. procumbens } \times \\
\text { L. dubia subsp. major } \\
\text { L. dubia subsp. major } \times \\
\text { L. procumbens }\end{array}$ & 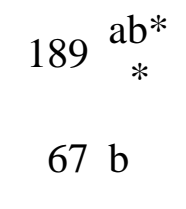 & $148 \mathrm{a}^{* *}$ & $33 \%$ & $67 \%$ & $33 \%$ & & & 0.22 & 0.01 \\
\hline & $\begin{array}{l}\text { L. procumbens } \times \\
\text { L. dubia subsp. dubia } \\
\text { L. dubia subsp. dubia } \times \\
\text { L. procumbens }\end{array}$ & $19 \mathrm{ab}$ & $4 \mathrm{a}$ & $-* * *$ & $100 \%$ & - & - & - & - & 0.89 \\
\hline & $\begin{array}{l}\text { L. dubia subsp. major } \times \\
\text { L. dubia subsp. dubia }\end{array}$ & $171 \mathrm{~b}$ & \multirow{2}{*}{$218 \mathrm{~b}$} & $11 \%$ & $53 \%$ & $11 \%$ & $5 \%$ & $19 \%$ & \multirow{2}{*}{0.30} & \multirow{2}{*}{$<0.01$} \\
\hline & $\begin{array}{l}\text { L. dubia subsp. dubia } \times \\
\text { L. dubia subsp. major }\end{array}$ & $295 \mathrm{a}$ & & $4 \%$ & $44 \%$ & $9 \%$ & $11 \%$ & $31 \%$ & & \\
\hline & $\mathrm{F}_{1}$ total & & & $10 \%$ & $66 \%$ & $11 \%$ & $3 \%$ & $10 \%$ & & $<0.01$ \\
\hline \multirow{4}{*}{$\begin{array}{l}\text { Self } \\
\text { fertilization }\end{array}$} & L. procumbens & & & & $75 \%$ & $13 \%$ & \multirow{3}{*}{$2 \%$} & $13 \%$ & & \\
\hline & L. dubia subsp. major & & & $2 \%$ & $67 \%$ & & & $30 \%$ & & \\
\hline & L. dubia subsp. dubia & & & $2 \%$ & $59 \%$ & & & $39 \%$ & & \\
\hline & Self fertilization total & & & $1 \%$ & $67 \%$ & $4 \%$ & $1 \%$ & $27 \%$ & & \\
\hline
\end{tabular}

* No germination (1): No germination occurred, No flower (2): More than one seed germinated but no plant bore flowers before withering, No seeds (3): More than one plant bore flowers but seeds were produced by less than 11 per one capsule in any flower, A few seeds (4): 11 to 100 seeds per one capsule were produced in any flowers, Normal(5): more than 101 seeds were produced in any flowers.

** Different letters indicate significant difference $(\mathrm{p}<0.05)$ (Student $\mathrm{t}$ test).

*** Not surveyed because the seeds were not produced. 
Table 3 Morphological traits of $\mathrm{F}_{1}$ and selfing plants of L. dubia subsp. major and L. dubia subsp. dubia. See Table 1 for details of each type.

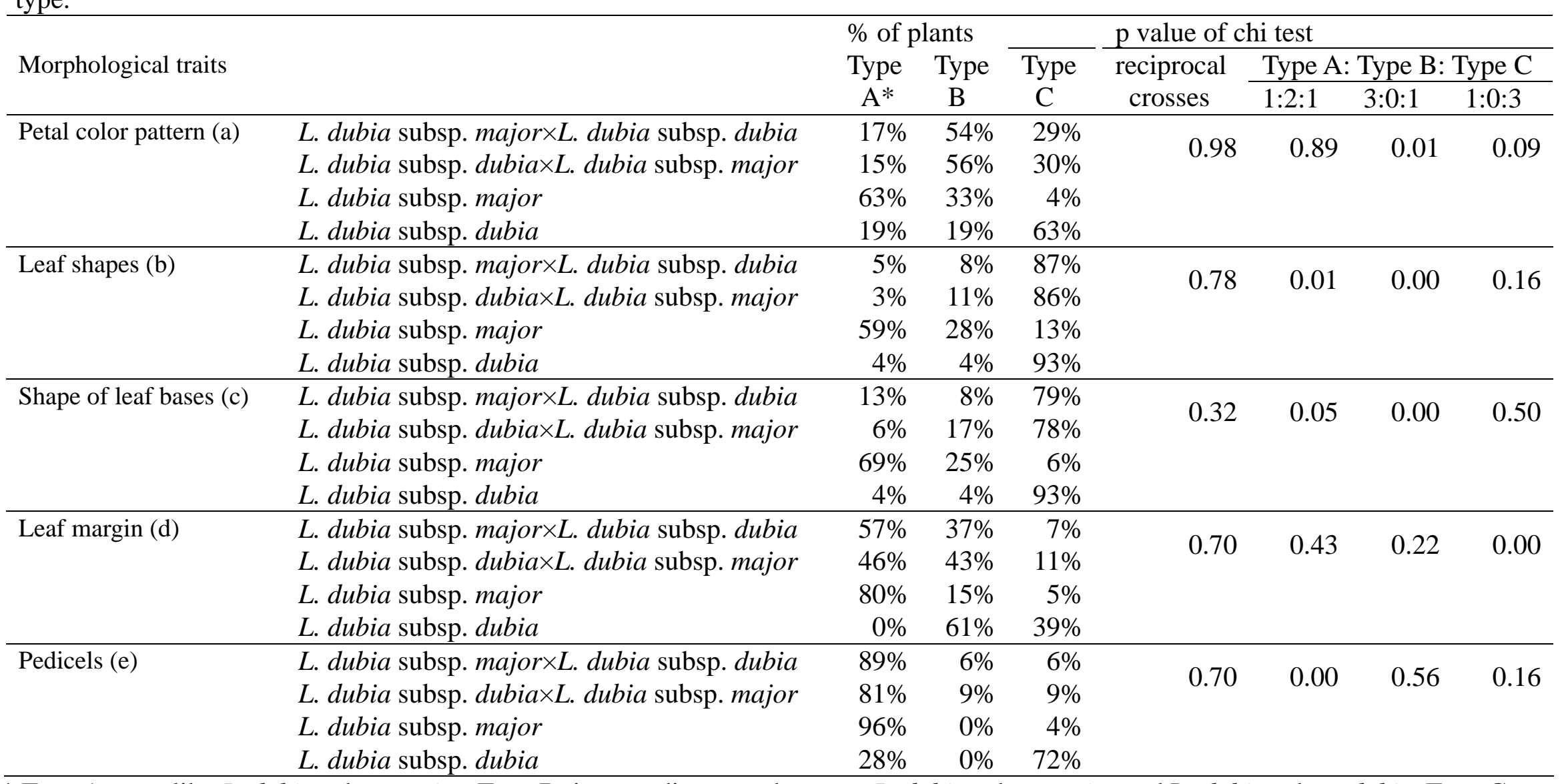

* Type A: type like L. dubia subsp. major, Type B: intermediate type between L. dubia subsp. major and L. dubia subsp. dubia, Type C: type like L. dubia subsp. dubia. Petal color pattern(a) - Type A: Margin: pink, spot: none, Type B: Margin: pale, spot: exist or none, Type C: Margin: deep purple, spot: exist. Leaf shapes (b) - Type A: Oblanceolate, Type B: Narrow elliptic lanceolate , Type C: Ovate. Leaf bases (c) - Type A: Attenueate cuneate, Type B: Obtuse elliptic , Type C: Rotund. Leaf margin (d) - Type A: Obviously serrate, Type B: Slightly obviously serrate $\sim$ unobviously serrate, Type C: Nearly entire $\sim$ entire. Pedicels (e) - Type A: Spiral at all nodes , Type B: Opposite at some nodes (not at all nodes), Type C: Opposite at all nodes. 